\title{
The effect of construction cost estimating (CCE) software on job performance: An improvement plan
}

\author{
M.F. Mohd Mukelas ${ }^{1}$, E.M. Ahmad Zawawi², Z. Alias ${ }^{3}$, K. Mohd. Sukur ${ }^{4}$ \\ 1,2,3,4 Department of Building, Faculty of Architecture, Planning \& Surveying, University Technology \\ MARA (UiTM), 40450 Shah Alam, Malaysia.
}

\begin{abstract}
This paper presents a comprehensive statistical research on the effect of construction cost estimating software's features towards estimating job performance. The objectives of this study are identification of cost estimating software features, analyzing the significant relation of cost estimating software's features towards job performance, Explore the problem faced during the implementation and lastly propose a plan to improve the cost estimating software usage among contractors in Malaysia. The study statistically reveals four features of cost estimating software that significantly impact towards changes in cost estimating job performance. These features were refined by performing interview to focus group of respondent to observe the actual possible problems during the implementation. Eventually, the proposed improvement plan was validated by the focus group of respondents to enhance the cost estimating software implementation among contractors in Malaysia.
\end{abstract}

\section{Introduction}

In Malaysia, the usage of cost estimating software was very limited [1]. Moreover, the commercial CCE software also has failed to meet the user's requirement especially in increasing estimating productivity and it was agreed by Mofti, 1]. When the current estimating programs are unable to fully satisfy their own users. Not only that, lack of strategic insights often resulting from poor ICT literacy and an inability to understand its potential. Thus, it shows lack of knowledge on benefits tapped for ICT application like commercial CCE software leading to lack of strategic development plan to further implement the software. Besides that, lacking in exposure on the guideline in enhancing usage of the software has badly impact to the contractor. It reduces the contractor's confidence level to invest into ICT. The same goes to the estimating software when the contractors as users lack of confidence in investing in ICT, to use the software as tool for their estimating activities. So that, unavailability of clear guideline on method to continuously and improve the software usage, then contractors will stay feel unprofitable to invest in this software due to unconfident on the benefits from the software outcome. Therefore, the establishment of framework to further improves the commercial CCE software usage is crucially needed in order to provide clear guideline to contractor to confidently invest in this software.

In addition, the global economic competition trend has also become apparent in construction industry, with client expecting a better service and project that meet their requirements more closely [2]. Plus with the bad reputation in construction industry delivery as similarly discussed by Kamarani 
[3]. the Malaysian construction industry faces serious problems such low productivity, heavy reliance on a large pool of unskilled and foreign labor and labor intensive construction techniques. Therefore, automation in construction industry is crucially needed in way to improve the construction performance. For example the construction industry has greatly earning benefit from the ICT through increasing the speed of information flow, enhancing the efficiency and effectiveness of information communication and reducing the cost of information transfer [4]. The ICT application widely used by contractors in all phases of construction activities. However, this reseach will disscuss more specific the effect of construction cost estimating software on job performance.

\section{Research Methodology}

The research used to conduct both primary and secondary data collection method, the primary data collection was conducted using quantitative method of questionnaire survey and qualitative method of interview session. However the secondary data were conducted using online databases from Science Direct, Scopus, Emerald, and American Society of Civil Engineer (ASCE), Building Economic journal, and Journal of construction technology. Literature was drawn to illustrate the breadth of knowledge on CCE software including features. These theoretical finding used to develop the questionnaire for second stage of quantitative data collection.

The survey was distributed among contractors in Malaysia that use the cost estimating software, the sample sizes were determined based on users listed by the software vendor. So that out of 82 questionnaires distributed by both hand and postage within 1st January 2013 to 15 March 2013, 63 were retrieved. Five (5) of the returns were found invalid because it was badly completed and therefore it was discarded. This produce new numbers of effective responds to 58, which represents a response rate of $70 . \%$. A response rate of $30 \%$ is good enough in construction studies.

The questionnaire contains 30 variables of cost estimating features. The variable represents features that available for the most cost estimating software in Malaysia. The features lists were collected from various sources including from electronic sources and meeting with software representative. It was further arranged according to cost estimating sequential of job and clearly explained in the previous chapter of literature review.

In term of the reliability of items in questionnaire, the data was tested using Cronbach's Alpha is 0.904 , which is more than 0.70 . This shows that the instrument used for this research is highly reliable. The survey data is analyzed using statistical Kruskall- Wallis test to measure the relationship between cost estimating software's features towards performance of the cost estimating job. According to Field [5], it is non parametric test of whether more than two independent groups differ . The test relies on scores being ranked from the lowest to the highest, which represent greater number of lowest score and greater number of highest score.

What is so important in this test is the significant value, which determines the group of studies that significantly give effect to the related factors. Any value that less than 0.5 is considered as significant because it gives us a lot of confidence that the significant effect is genuine [5]. So that, finally the discussion will take place to throw an opinion and reason for the outcome specifically to significant factors and groups.

The significant variable is then further investigated to explore its problems especially during the implementation. The only ways to find reliable and relevant data with regards to detail problems during the implementation, therefore interview was conducted within 20 focus groups of questionnaire respondent. Advantages of having qualitative method of research point out by homestead.com. as getting depth and detail information compared to standardized questionnaire, openness in generating new theories and recognize phenomena. So that, the interview method is capable to help researcher to find data that cannot be collected by questionnaire survey. 


\section{Result and Discussion}

\subsection{Variable related to construction cost estimating software features}

Referring to Table 1, both study of CCE knowledge [6]. which explore ISO standard procedure of contractor's estimating procedure and CCES features which collected from actual software features offers by different types of CCES known as Masterbill [7], Buildsoft [8], Ripac[9]., CSSP Goldenseal estimate, turtlesoft.com [12], and benchmark estimating software, benchmark estimating.com [11]. Finally, both informations were combined to form a summary of CCES features that devided carefully according to CCES activity and procedure.

Table 1: List of variable related to CCE software features

\begin{tabular}{|c|c|}
\hline CCE activity & CCES features \\
\hline $\begin{array}{l}\text { Quotation } \\
\text { invitation to sub } \\
\text { contractor }\end{array}$ & $\begin{array}{l}\text { Create a quote in Microsoft Word based on your own template designs. } \\
\text { Links material and labor prices to vendors and subcontractors }\end{array}$ \\
\hline $\begin{array}{l}\text { Tender estimation } \\
\text { taking off }\end{array}$ & $\begin{array}{l}\text { Calculates quantity of materials required for a job } \\
\text { Calculates quantity of labor required for a job } \\
\text { Generates purchase orders and work orders based on take-off } \\
\text { Links material and labor prices to vendors and subcontractors } \\
\text { Utilizes master database of material Items } \\
\text { Allows for use of assemblies in take-off } \\
\text { Provides material quantity reporting } \\
\text { Generates price comparison reports } \\
\text { Integrates with take-off packages and digitizers } \\
\text { integrate with third party quantity takeoff software using Takeoff Integrator }\end{array}$ \\
\hline $\begin{array}{l}\text { Material/Labor/E } \\
\text { quipment usage } \\
\text { calculation }\end{array}$ & $\begin{array}{l}\text { The Spread feature allows you to manipulate your submission price on an Item by Item } \\
\text { basis } \\
\text { Routines feature is easy-touse and designed to handle repetitive activities. latest } \\
\text { Resource prices from your central Resource Library build the estimate for you. }\end{array}$ \\
\hline Estimate checked & $\begin{array}{l}\text { Easily modify and add cost data to suit your local conditions and business. } \\
\text { The Cost Check feature is ideal for updating previous estimates with current prices. It } \\
\text { determines price are out of date and elect to update all. }\end{array}$ \\
\hline Final summary & $\begin{array}{l}\text { Benchmark Estimating Software gives you over } 80 \text { individual reports for each Project } \\
\text { these include bill of materials, Resource usage and estimate review reports }\end{array}$ \\
\hline $\begin{array}{l}\text { Quotation replied } \\
\text { by sub contractor }\end{array}$ & $\begin{array}{l}\text { Benchmark Estimating Software gives you over } 80 \text { individual reports for each Project } \\
\text { these include bill of materials, Resource usage and estimate review reports } \\
\text { All reports can be exported to Microsoft Word, Excel and PDF formats giving you a } \\
\text { clear, transparent format for management to review an estimate } \\
\text { Project templates make it easy to estimate "standard" types of projects Estimate and } \\
\text { project management reporting } \\
\text { All the Resources for each Item in your bid can be viewed in one screen, making it fast } \\
\text { and easy to review and edit details of your bid and ensuring maximum accuracy within } \\
\text { your estimates }\end{array}$ \\
\hline $\begin{array}{l}\text { Quotation replied } \\
\text { by sub contractor }\end{array}$ & competitive bid tracking handles price quotes from suppliers and subcontractors \\
\hline $\begin{array}{l}\text { Compile final cost } \\
\text { figure }\end{array}$ & $\begin{array}{l}\text { Client's schedule of Items is loaded electronically, eliminating the need to retype } \\
\text { details. } \\
\text { Import multiple Items from library to one Item in schedule, giving amazing flexibility to } \\
\text { bid any job, regardless of client specifications. } \\
\text { The flexibility is in your hands with the popular quote with options report, and the } \\
\text { ability to create a quote in Microsoft Word based }\end{array}$ \\
\hline $\begin{array}{l}\text { Checking on } \\
\text { profit/loss } \\
\text { tabulation }\end{array}$ & $\begin{array}{l}\text { Extras allow add profit (mark-up) as an overall percentage or as a lump sum. You can } \\
\text { add different mark-up percentages to your Labour, Plant, Materials and Subcontract } \\
\text { components. }\end{array}$ \\
\hline $\begin{array}{l}\text { Approved \& } \\
\text { tender submission }\end{array}$ & $\begin{array}{l}\text { Manipulate your submission price on an Item by Item basis. The spread can be print out } \\
\text { item by item according to BQ listed and make it easy for tender pricing }\end{array}$ \\
\hline
\end{tabular}




\subsection{Variable related to cost estimating performance}

The above figure explains the CCE performance (Tender price) and CCE preparation is related each other. The researcher conclude the evidence above by defining contractor cost estimate (CCE) preparation as a process to built up the unit price of construction resources according to a given tender document, which finally used to multiple with a given quantity in Bill of quantity document (BQ) to produce a total cost known as tender price. The tender price is then further evaluated by client to be awarded.

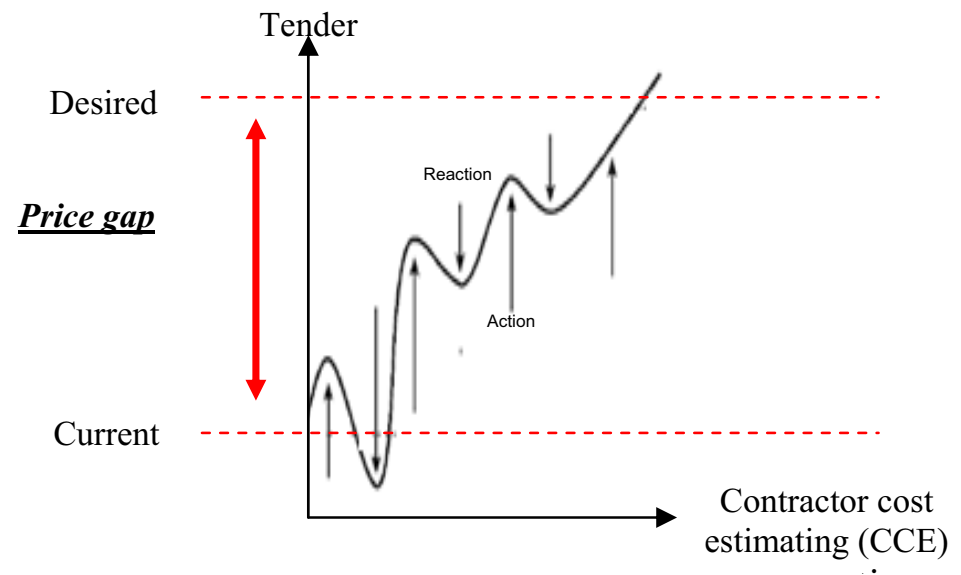

Figure 1: Proposed of CCE software performance model

Referring back to Figure 2, it shows both current performance and desired performance. In this research context, these are very important element in determine the CCE performance in term of tender performance. As discussed before, other method of measuring tender performance was plenty of biases and therefore, researcher was decided to used and compare both current and desired performance in order to identify the power of CCE software against CCE performance. Then, the following discussion explains in depth on both current and desired performance with respect to this research context

\section{i) Current performance}

In this research context, the researcher defines a current performance as a proposed tender price promoted by contractor to respective client in a given set of tender. Since this research is focusing on the usage of CCE software during preparing CCE for tender price, therefore contractor with CCE software implementation will be evaluated.

\section{ii) Desired performance}

Meanwhile desired performance refers to the lowest tender price for a similar tender project. This is relevant when contractor invest to use CCE software with objective for improving the accuracy and assist in preparation tender price which eventually increase the potential to be awarded. So that, the lowest tender price became a benchmark for contractor to measure the CCE performance in term of tender price. Basically, the client will display the tender price after the submission date to the public. The practice was used in Malaysia especially for open tendering procurement method. The display only shows the ranking and the proposed tender price and invisible the company names. Normally, the lowest tender price will be ranked at first and it ascents downward up to total numbers of contractor join to compete the tender. So that, the $1^{\text {st }}$ ranking which indicates the lowest tender price need to identify and further compare with the own tender price. 


\subsection{Statistical results of relationship between CCE software features against performance}

Table 2: Significance variables of CCE software features against cost estimating performance

\begin{tabular}{|l|c|c|c|c|c|c|}
\hline \multicolumn{1}{|c|}{$\begin{array}{c}\text { (Performance of estimating software } \\
\text { Group of variable }\end{array}$} & $\begin{array}{c}\text { Chi- } \\
\text { Square }\end{array}$ & $\mathrm{df}$ & $\begin{array}{c}\text { Asymp. } \\
\text { Sig. }\end{array}$ & $\begin{array}{c}\text { Monte } \\
\text { Carlo } \\
\text { Sig. }\end{array}$ & $\begin{array}{c}\text { 95\% of Confidence } \\
\text { Interval }\end{array}$ \\
\cline { 5 - 8 } & & $\begin{array}{c}\text { Lower } \\
\text { bound }\end{array}$ & $\begin{array}{c}\text { Upper } \\
\text { bound }\end{array}$ \\
\hline $\begin{array}{l}\text { Online quote invitation via email to } \\
\text { supplier or sub contractor }\end{array}$ & 4.082 & 4 & .039 & $.043^{\mathrm{a}}$ & .042 & .045 \\
\hline $\begin{array}{l}\text { The cost check feature is ideal for } \\
\text { updating price quote with current } \\
\text { prices. It determines prices are out of } \\
\text { date and update all. }\end{array}$ & 1.476 & 3 & .048 & $.037^{\mathrm{a}}$ & .041 & .044 \\
\hline $\begin{array}{l}\text { All reports can be exported to Microsoft } \\
\begin{array}{l}\text { Word, Excel and PDF formats giving } \\
\text { you a clear, transparent format for } \\
\text { management to review an estimate }\end{array}\end{array}$ & 7.720 & 3 & .048 & $.038^{\mathrm{a}}$ & .035 & .042 \\
\hline $\begin{array}{l}\text { Import multiple Items from library to } \\
\text { one Item in schedule, giving amazing } \\
\text { flexibility to bid any job, regardless of } \\
\text { client specifications. }\end{array}$ & 12.049 & 3 & .007 & $.001^{\mathrm{a}}$ & .000 & .001 \\
\hline
\end{tabular}

Table 2: Cross tabulation table of significance variable against cost estimating performance

\begin{tabular}{|c|c|c|c|}
\hline Variable & Satisfaction level & $\mathbf{N}$ & Mean Rank \\
\hline \multirow{6}{*}{$\begin{array}{l}\text { Performance of measurement } \\
\text { (Lowest cost) } \\
\text { Online quote invitation via } \\
\text { email to supplier or sub } \\
\text { Contractor }\end{array}$} & Not satisfy at all & 10 & 12.80 \\
\hline & Slightly satisfy & 8 & 11.13 \\
\hline & Satisfy & 2 & 12.00 \\
\hline & Very satisfy & 2 & 17.00 \\
\hline & Extremely satisfy & 1 & 1.00 \\
\hline & Total & 23 & \\
\hline \multirow{5}{*}{$\begin{array}{l}\text { Performance of measurement } \\
\text { (Lowest cost)* } \\
\text { The cost check feature is ideal } \\
\text { for updating price quote with } \\
\text { current prices }\end{array}$} & Slightly satisfy & 2 & 7.50 \\
\hline & Satisfy & 8 & 11.13 \\
\hline & Very satisfy & 10 & 13.25 \\
\hline & Extremely satisfy & 3 & 13.17 \\
\hline & Total & 23 & \\
\hline \multirow{5}{*}{$\begin{array}{l}\text { Performance of measurement } \\
\text { (Lowest cost) } \\
\text { All reports can be exported } \\
\text { to Microsoft Word, Excel and PDF formats }\end{array}$} & Slightly satisfy & 4 & 14.63 \\
\hline & Satisfy & 12 & 8.58 \\
\hline & Very satisfy & 4 & 14.13 \\
\hline & Extremely satisfy & 3 & 19.33 \\
\hline & Total & 23 & \\
\hline \multirow{5}{*}{$\begin{array}{l}\text { Performance of measurement } \\
\text { (Lowest cost) } \\
\text { Import multiple Items from } \\
\text { library to one Item in schedule }\end{array}$} & Slightly satisfy & 14 & 8.21 \\
\hline & Satisfy & 3 & 18.33 \\
\hline & Very satisfy & 5 & 16.70 \\
\hline & Extremely satisfy & 1 & 22.50 \\
\hline & Total & 23 & \\
\hline
\end{tabular}

Combination between both statistical results in table 2 and table 3 is important to interpret the results of effect CCE software features against its job performance. As discussed in previous methodology chapter, table 2 shows the significant variable against cost estimating performance and the table 3 use to broaden the significant result towards satisfaction by users. Firstly, the online quote invitation via email to supplier or subcontractor towards its performance, $\mathrm{H}(4), 4.082, \mathrm{p}<0.05$ (refer table 2) and the highest frequency within its satisfaction group (frequency $=10$ ) at "Not satisfy at all" 
(refer table 3). The bad internet infrastructure and unavailability of expertise to respond the contractor's online quotation make the vendors and subcontractors refuse to use online quotation and prefer to use manually using facsimile transfer. This is very bad for contractors to fully automate their cost estimating activities.

The combination between cost check features towards its performance also seen having the significance differences, $\mathrm{H}(3), 1.476, \mathrm{p}<0.05$ (refer Table 2) and the highest frequency within satisfaction group (frequency $=10$ ) at "Very satisfy" (refer Table 3 ). This result was generally affected from the excellent features performance, which make user feel easy to track anything error in during the cost estimating works. It improve the accuracy by limiting the cost price error and finally produce very competitive tender price.

Other than that, there is also significance different between Exporting report to various format of Microsoft word, Excell and PDF towards its performance. H(3), 7.720, p $<0.05$ (refer Table 2) and the highest frequency within the satisfaction group (frequency $=12$ ) at "Satisfy". (refer Table 3). Most of the user are convenience with this features, it is useful especially when the vendor or sub contractor demand for quotation with different formatting. This make contractor feel happy and generally satisfy to help them in preparing better tender price.

Features of Library also shows significance differences against its performance, H (3), 12.049, $p<0.05$ and the highest frequency within the satisfaction group (frequency=14) at "satisfy". The library function to store the prices and keep it updated to be used to price the tender has improve the price searching activities. It capable to give the latest prices based on previous project within just a minute without go through the quotation process. So that, the user can earns the benefits of easiest and fastest tender price rate searching

\section{Conclusion And Recommendation}

In conclusion, the research found more than 30 features used for CCE software through the comprehensive journal review of secondary data. Besides, the method to measure the CCE performance was found to be effected from the automation in doing cost estimating activities. These two independent variables were statistically tested and reveal only four of them has significant relationship each others. Eventually, these significant variables were further tested more using cross tabulation in effort to determine its effect against CCE performance to be negative or positive. Therefore, the following table are summary of recommendation of improvement plan towards better implementation among contractors in Malaysia.

\begin{tabular}{|c|c|c|}
\hline $\begin{array}{l}\text { CCE software } \\
\text { features }\end{array}$ & Problems (Interview) & Improvement plan (Proposed) \\
\hline $\begin{array}{l}\text { Online quote } \\
\text { invitation }\end{array}$ & $\begin{array}{l}\text { The third parties such sub contractors } \\
\text { and supplier refuse to use the online } \\
\text { application to respond the quotation } \\
\text { because of unavailability in expertise and } \\
\text { ICT infrastructure. }\end{array}$ & $\begin{array}{l}\text { Sub contractors and suppliers especially } \\
\text { those from Small Medium Enterprise } \\
\text { (SME) should invest more in ICT } \\
\text { infrastructure and hire staff with ICT } \\
\text { knowledge and skills }\end{array}$ \\
\hline $\begin{array}{c}\text { The cost check } \\
\text { feature. }\end{array}$ & $\begin{array}{l}\text { The cost check features in not working } \\
\text { well to update the prices to be relevant } \\
\text { especially in ensuring the accuracy for } \\
\text { different project location }\end{array}$ & $\begin{array}{l}\text { The software developer should integrate } \\
\text { GPS with cost check features to ensure } \\
\text { the prices can be updated according to } \\
\text { location of project }\end{array}$ \\
\hline $\begin{array}{l}\text { All reports can be } \\
\text { exported to } \\
\text { Microsoft Word, } \\
\text { Excel and PDF } \\
\text { formats }\end{array}$ & $\begin{array}{l}\text { The report is too rigid and limits users to } \\
\text { custom the price and specification } \\
\text { especially when it is needed by the } \\
\text { suppliers and sub contractors. }\end{array}$ & $\begin{array}{l}\text { The software developer should allow for } \\
\text { the users to have greater flexibility in } \\
\text { extracting the virtual information as to } \\
\text { cater the quotation needs }\end{array}$ \\
\hline $\begin{array}{l}\text { Import multiple } \\
\text { Items from library to } \\
\text { one Item in schedule }\end{array}$ & $\begin{array}{l}\text { Basically, there is no department } \\
\text { assigned to control the library, in order to } \\
\text { keep it updated. It reduce its usage to } \\
\text { save time in looking the best price during } \\
\text { the estimating process. }\end{array}$ & $\begin{array}{l}\text { The contractors should introduce } \\
\text { department that specifically designated to } \\
\text { manage the library. Functioning to keep } \\
\text { the prices updated and relevant to be } \\
\text { used }\end{array}$ \\
\hline
\end{tabular}




\section{References}

1. Marjuki, M. b. (2006). Computerize building estimating system. Thesis .

2. Sarah Bowden, Alex Dorr, Tony Thorpe, Chimay Anumba. (2005, August 30). Mobile ICT support for construction process improvement. Automation in Construction, 664-676.

3. Kamarani, M. K. (2002). Reforming Malaysian Construction Technology Towards. Asian Forum 2002. Kuala Lumpur: CIDB Malaysia.

4. Yuan Chen, J. M. (2011). A framework for using mobile computing for information management on construction sites. Automation in construction, 001-013.

5. Andy Field (2009) Discovering statistic using SPSS Textbook, $4^{\text {th }}$ Edition

6. Fang, L. T. (2006). ISO 9001:2000 Quality management system in construction- Tendering procedure. Thesis .

7. Masterbill. (2012). Retrieved 10 2, 2012, from http://www.masterbill.com/1/default.asp

8. Buildsoft. (2011). Retrieved 10 2, 2012, from http://www.buildsoft.com/index.asp

9. Ripac. (2002). Retrieved 10 2, 2012, from http://www.cssp.co.uk/content/products/ripac.php

10. turtlesoft.com. (2006). Retrieved from http://www.turtlesoft.com/Estimating-Software.html

11. benchmarkestimating.com. (2012). Retrieved $10 \quad 8, \quad 2012$, from http://benchmarkestimating.com/industries/civil/

12. Homestead.com (2011) Retrieved 9 1, 2012, from http://www.homestead.com/qualitative data

13. Martin Sexton \& Peter Barrett. (2010). Appropriate innovation in small construction firms. Construction Management and Economics , 623-633. 